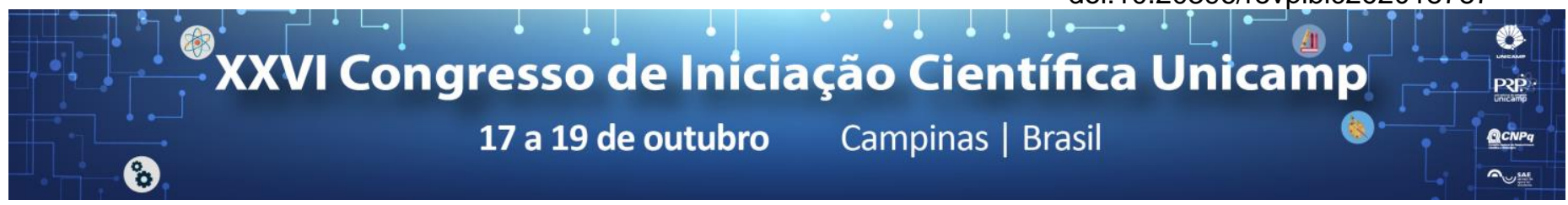

\title{
Os frames nos protestos contra a corrupção do Mensalão e da Lava Jato
}

\author{
Aluna: Larissa Melo*, Orientadora: Luciana Tatagiba
}

\section{Resumo}

O objetivo da pesquisa foi analisar os frames das manifestações anticorrupção do Mensalão e da Lava Jato. Filtrei as notícias de protestos através do banco de dados "Confronto político no Brasil (1998-2016)" e em seguida fiz uma análise de conteúdo das imagens relacionadas aos escândalos de corrupção. A investigação sobre os frames apontaram três resultados: Dilma foi atacada de forma mais direta pelos frames na época da Lava Jato, enquanto isso, os frames relacionados a Lula na época do Mensalão foram mais cautelosos, a associação entre PT e corrupção foi mais frequente nos protestos da Lava Jato, bem como a coesão ideologica dos frames.

\section{Palavras-chave:}

Protestos, Corrupção, Frames.

\section{Introdução}

O objetivo dessa pesquisa é compreender como a corrupção apareceu nos frames (enquadramentos que simplificam e condensam as lutas políticas) dos protestos anticorrupção do Mensalão e da Lava Jato.

A característica mais importante da literatura relacionada ao Mensalão é como o presidente Lula ficou a margem do escândalo, os autores trabalhados defenderam que Lula foi blindado ${ }^{1}$ ou, no mínimo, a oposição e a imprensa tiveram uma postura de cautela ${ }^{2}$ ao relacioná-lo ao Mensalão. Essa postura da oposição com Lula contrastaria com ação dos adversários de Dilma no escândalo da Lava Jato. Com Dilma, os ataques foram diretos ${ }^{5}$, agressivos e até misógenos.

Partindo das considerações da literatura, investiguei se os frames nos protestos anticorrupção expressaram cautela no governo Lula e, se no governo Dilma, foram mais agressivos e diretos.

\section{Resultados e Discussão}

Para realizar o trabalho filtrei no banco de dados "Confronto político no Brasil (1998-2016)" os protestos anticorrupção do Mensalão que aconteceram no ano de 2005 e os da Lava Jato no ano de 2015. O banco é produzido pelo Nepac em conjunto com o Cemarx, o método de coleta é a Análise de Evento de Protesto ${ }^{4}$ e a fonte para os dados é a Folha de São Paulo. Após a filtragem, fiz uma análise de conteúdo ${ }^{3}$ das imagens, no qual, construi uma classificação para os frames, por exemplo, na categoria "Impeachment" coloquei frames como "Impeachement Já" e "Pelo impeachment de Dilma/Lula"; na categoria "Corrupção abstrata" coloquei imagens que não apareciam frames, mas que os símbolos evocados na foto remetiam a corrupção como limpeza, nariz de palhaço, etc.

O banco de dados nos mostrou 55 "ocorrências de protestos" cujo objetivo envolvia o Mensalão, desses protestos, captei 70 imagens.Em 2015, os protestos contra a corrupção foram 42 ocorrências, desse universo captei 35 imagens. Os gráficos a seguir apontam a frequência que cada frame apareceu de acordo com as categorias criadas:
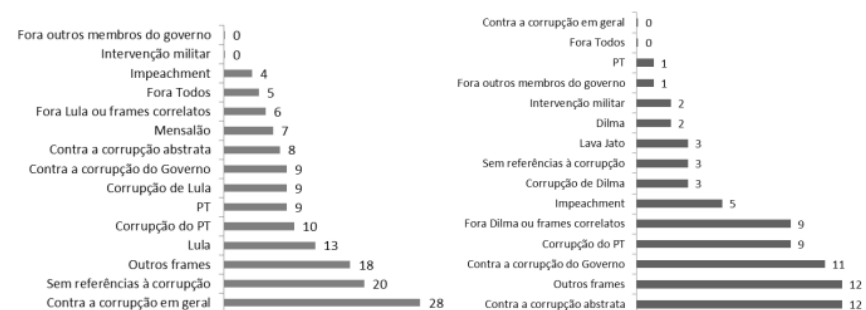

O primeiro gráfico refere-se aos protestos anticorrupção do Mensalão e o segundo aos da Lava Jato.

\section{Conclusões}

Os dados captados corroboram com a hipótese. Dilma foi atacada de forma mais direta pelos frames, predominando os pedidos de "Fora Dilma" e "Impeachment Já", enquanto isso, os frames contra Lula foram mais cautelosos, já que houve poucos pedidos de impeachment e o frame "Lula sabia [do mensalão]" é um bom exemplo do humor das ruas. Outros resultados que apareceram ao longo da pesquisa mostraram que Em seguida, foi possível perceber que a associação entre corrupção e PT foi diferente nos dois escândalos, nos protestos da Lava Jato, o PT estava sempre associado à corrupção. Por último, constatei que as demonstrações motivadas pela Lava Jato tinham um enquadramento mais coeso ideologicamente, fator que pode atuar no incremento das mobilizações de 2015 , em relação as de 2005.

\section{Agradecimentos}

À minha orientadora pela disposição e incentivo. À Unicamp e ao CNPq pelo suporte.

\footnotetext{
${ }^{1}$ MARTUSCELLI, D. E. As lutas contra a corrupção nas crises políticas brasileiras: 1992, 2005, 2015. Crítica e Sociedade: revista de cultura política, Uberlândia, v. 6, n. 2, 2016.

${ }^{2}$ MIGUEL, L. F.; COUTINHO, A. DE A. A crise e suas fronteiras: oito meses de "mensalão" nos editoriais dos jornais. Opinião Pública, Campinas, v. 13, n. 1, p. $97-123$, jun. 2007

${ }^{3}$ NEUENDORF, K. A. The Content Analysis Guidebook. [s.1.] SAGE, 2002.

${ }^{4}$ TATAGIBA, L; GALVÃO, L. Livro de códigos "Confronto político no Brasil (1998-2016)", mimeo.

${ }^{5}$ TATAGIBA, L. Os protestos e a crise brasileira. Um inventário inicial das direitas em movimento (2011-2016). Revista Sinais Sociais, Dossiê: A ciência política e a crise no Brasil. v. 11, p. 71-98, 2017.
} 